Jurnal Perikanan (2021) Volume 11. No. 2 : 209-217

DOI : https://doi.org/10.29303/jp.v11i2.257

\title{
PEGARUH SUBSTRAT BERBEDA TERHADAP PENEMPELAN TELUR PADA PEMIJAHAN IKAN BADUT (Amphiprion Ocellaris)
}

\section{EFFECT OF DIFFERENT SUBSTRATES ON EGG ATTACHMENT ON CLEAR FISH (Amphiprion ocellaris) SPAWNING}

\author{
Velita oktavianti $^{1)}$, Nunik Cokrowati ${ }^{1 *}$, Bagus Dwi Hari Setyono ${ }^{1}$ \\ 1) Program Studi Budidaya Perairan, Fakultas Pertanian Universitas Mataram \\ Jl. Majapahit No.62 Mataram 83115 Nusa Tenggara Barat \\ *)alamat korespondensi: nunikcokrowati@unram.ac.id
}

\begin{abstract}
Abstrak
Pada pemijahan ikan badut dibutuhkan sebuah perlakuan pada manipulasi tempat asal ikan badut untuk melakukan pemijahan pada wadah budidaya. Substrat genteng dan keramik cocok untuk penempelan larva ikan badut karena tekstur dari ke dua substrat tersebut keras, hal ini menunjukkan bahwa jenis substrat keras akan dapat di jadikan tempat hidup ikan badut, karena sifat ikan badut harus tumbuh dan berkembang dalam substrat keras. Penelitian ini dilakukan dengan tujuan untuk mempelajari perbedaan kelangsungan hidup larva ikan badut pada substart berbeda. Penelitian ini dilakukan selama 45 hari, terhitung mulai tanggal 1 september sampai tanggal 15 oktober 2021 di Balai Perikanan Budidaya Laut Lombok (BPBLL). Metode yang di lakukan dalam penelitian adalah dengan menggunakan metode eksperimen dengan pola Rancangan Acak Lengkap (RAL) dengan empat perlakuan 3 kali ulangan, yaitu P1 (substrat keramik), P2 (substrat genteng), P3 (substrat paralon), P4 (substrat gerabah). Hewan uji yang di gunakan pada penelitian ini adalah indukan ikan badut (Amphiprion ocellaris) jantan dan betina yang berumur berkisar antara 4-5 tahun. Berdasarkan penelitian yang sudah di lakukan terdapat hasil fertilisasi $\mathrm{P} 1=88.67 \%, \mathrm{P} 2=$ 94.17\%, P3 $=83.83 \%, \mathrm{P} 4=78.67 \%$. Sedangkan hasil daya tetas $\mathrm{P} 1=88.67 \%, \mathrm{P} 2=94.17 \%$, $\mathrm{P} 3=83.83 \%, \mathrm{P} 4=78.67 \%$. Dan hasil dari kelangsungan hidup $\mathrm{P} 1=82.15 \%, \mathrm{P} 2=82.84 \%$, $\mathrm{P} 3=80.94 \%, \mathrm{P} 4=80.11 \%$. Kesimpulan dari penelitian ini adalah bahwa penggunaan substrat keramik, genteng, paralon, dan gerabah memberikan pengaruh terhadap fertilisasi dan daya tetas telur ikan badut. Kelangsungan hidup tidak berpengaruh nyata terhadap penggunaan substrat pada pemijahan ikan badut.
\end{abstract}

Kata kunci : Budidaya, ikan hias, laut, fertilisasi, daya tetas.

\begin{abstract}
In spawning clown fish it takes a treatment on the manipulation of the place of origin of clown fish to spawn in cultivation containers. Tile and ceramic substrates are suitable for the attachment of clownfish larvae because the texture of the two substrates is hard, this indicates that the type of hard substrate will be able to be made a living place for clownfish, because the properties of clown fish must grow and develop in hard substrates. This research was conducted with the aim of studying differences in the survival of clown fish larvae on
\end{abstract}


different substrates. This research was conducted for 45 days, starting from 1 September to 15 October 2021 at the Lombok Marine Cultivation Fisheries Center (BPBLL). The method used in this research is to use an experimental method with a completely randomized design (CRD) pattern with four treatments with 3 replications, namely P1 (ceramic substrate), P2 (tile substrate), P3 (paralon substrate), P4 (pottery substrate). . The test animals used in this study were male and female clown fish (Amphiprion ocellaris) aged between 4-5 years. Based on the research that has been done, there are fertilization results $\mathrm{P} 1=88.67 \%, \mathrm{P} 2=$ $94.17 \%, \mathrm{P} 3=83.83 \%, \mathrm{P} 4=78.67 \%$. While the results of hatchability $\mathrm{P} 1=88.67 \%, \mathrm{P} 2=$ $94.17 \%, \mathrm{P} 3=83.83 \%, \mathrm{P} 4=78.67 \%$. And the results of survival were $\mathrm{P} 1=82.15 \%, \mathrm{P} 2=$ $82.84 \%, \mathrm{P} 3=80.94 \%, \mathrm{P} 4=80.11 \%$. The conclusion of this study was that the use of ceramic, tile, paralon, and earthenware substrates had no effect on fertilization and hatchability of clown fish eggs. The survival of clown fish has a significant effect on the use of substrate in spawning clown fish.

Keywords: Aquaculture, ornamental fish, marine, fertilization, hatchability.

\section{PENDAHULUAN}

Keanekaragaman hayati merupakan kata yang di gunakan untuk mendeskripsikan kelimpahan aneka macam bentuk kehidupan pada bumi. Sebagai negara kepulauan dan negara maritim terbesar, Indonesia mempunyai taraf keanekaragaman biologi bahari tertinggi pada dunia. Ikan mempunyai beranekaragam jenis dan bentuk dari yang menarik sampai yang tidak menarik. Ikan yang mempunyai bentuk dan jenis yang menarik umumnya di jadikan ikan hias sebagai salah satu pemanfaatan atau budidaya ikan hias banyak di Indonesia.

Berdasarkan data produksi dari tahun 2009-2015 mencapai 1,31 miliar ekor. Ikan badut adalah salah satu komoditas ikan hias laut yang banyak diminati. Setiawati et al. (2012), menyatakan bahwa kelebihan pada ikan badut merupakan taraf perkembangbiakan yang sangat tinggi. Ikan badut mempunyai umur dengan rentang 3 hingga 10 tahun sehingga ikan badut dapat bertelur sebanyak 72 kali hingga 360 kali.

Keberhasilan pemijahan sangat dipengaruhi oleh banyak faktor, diantaranya perlakuan induk, teknik pemijahan, penetasan telur, penanganan larva dan penggunaan substrat (Edwar 2016). Ikan badut merupakan ikan yang sulit berkembang biak di luar habitatnya. Pada pemijahan ikan badut dibutuhkan sebuah perlakuan pada manipulasi tempat asal ikan badut untuk melakukan pemijahan pada wadah budidaya. Salah satunya dapat menggunakan banyak sekali macam substrat yang cocok untuk tempat menempelnya ikan badut (Kadek 2018).

Berbagai macam substrat yang dapat di gunakan untuk pemijahan ikan badut diantaranya genteng, keramik, dan paralon. Substrat genteng dan keramik cocok untuk penempelan larva ikan badut karena tekstur dari ke dua substrat tersebut keras, hal ini menunjukkan bahwa jenis substrat keras akan dapat di jadikan tempat hidup ikan badut, karena sifat ikan badut harus tumbuh dan berkembang dalam substrat keras. Tujuan dari penelitian ini adalah untuk mengetahui perbedaan pertumbuhaan telur dan kelangsungan hidup larva ikan pada substrat berbeda.

\section{METODE PENELITIAN Waktu dan tempat penelitian}

Penelitian di lakukan pada bulan September hingga oktober 2021, di Balai Perikanan Budidaya Laut Lombok (BPBLL). 


\section{Alat dan Bahan}

Alat-alat yang di gunakan dalam penelitian ini adalah akuarium, bak fiber, Thermometer, $\mathrm{pH}$ meter, Dissolve Oxygen meter, pipa, keramik, genteng, paralon, gerabah. Bahan- bahan yang di gunakan adalah indukan ikan badut serta pakan alami dan buatan.

\section{Prosedur penelitian Persiapan wadah}

Persiapan Wadah dan Adaptasi Wadah yang digunakan berupa akuarium kaca sebesar 1 buah dengan ukuran (40x 30 x 50) cm yang di lengkapi dengan saluran inlet dan outlet yang terbuat oleh pipa PVC menggunakan diameter $20 \mathrm{~mm}$. Akuarium diisi menggunakan air laut dengan ketinggian $30-40 \mathrm{~cm}$. Kemudian, sepasang induk ikan badut dimasukkan kedalam akuarium tersebut.

\section{Pemeliharaan larva dan pemberian pakan}

Pemeliharaan larva ikan badut pada pelihara dalam akuarium kaca dengan kapasitas air $30 \mathrm{~cm}$. Pemberian pakan alami di berikan selama 30 hari dan pada hari ke-20 dapat diberikan pakan tambahan berupa pakan buatan pellet, pembeian pakan di lakukan minimal 2 kali sehari yaitu pada pagi dan sore hari.

\section{Parameter penelitian Fertilisasi}

Fertilization rate (FR) telur dihitung dengan cara membandingkan telur yang dibuahi dengan jumlah yang diinkubasi. Hui et al (2017):

$$
\text { Fertilisasi }=\frac{\text { telur terbuahi }}{\text { total telur }} \times 100 \%
$$

\section{Kelangsungan Hidup (SR)}

Menurut Laheng (2019), kelangsungan hidup ikan dapat dihitung dengan penggunaan rumus berikut:

$$
\operatorname{SR}(\%)=\frac{N t}{N o} \times 100 \%
$$

Keterangan:

$\mathrm{SR}=$ Tingkat kelangsungan hidup (\%)

$\mathrm{Nt}=$ Jumlah ikan pada akhir penelitian (ekor)

No = Jumlah ikan pada awal penelitian (ekor)

\section{Daya tetas}

HR telur ikan dihitung dengan cara menghitung larva satu persatu, kemudian dinyatakan dalam persen. Hui et al, (2017):

$$
\operatorname{Hr}(\%)=\frac{\text { jumlah telur menetas }}{\text { jumlah telur sample }} \times 100
$$

$\mathrm{Hr}=$ daya tetas telur

\section{Analisis data}

Data yang didapatkan dari penelitian adalah persentase kelangsungan hidup ikan badut yang dianalisis menggunakan sidik ragam (anova) dengan tingkat kepercayaan 95\%. Apabila data menunjukkan hasil berpengaruh nyata maka dilakukan uji lanjut (BNT). Sedangkan data parameter kualitas air yang mencakup nilai $\mathrm{pH}$, suhu dan oksigen terlarut dijelaskan secara deskriptif.

\section{HASIL}

\section{Fertilisasi}

Berdasarkan penelitian yang sudah di lakukan pembuahan telur tertinggi terdapat pada P2 sebesar $94,17 \%$, selanjutnya pada P1 sebesar 88,67\%, kemudian pada P3 sebesar $83,83 \%$, dan nilai terendah pada P4 yaitu $78,67 \%$. Hasil uji statistik yang didapatkan bahwa P2 berbeda nyata dengan P1, P3, P4. 
Jurnal Perikanan (2021) Volume 11. No. 2 : 209-217

DOI : https://doi.org/10.29303/jp.v11i2.257

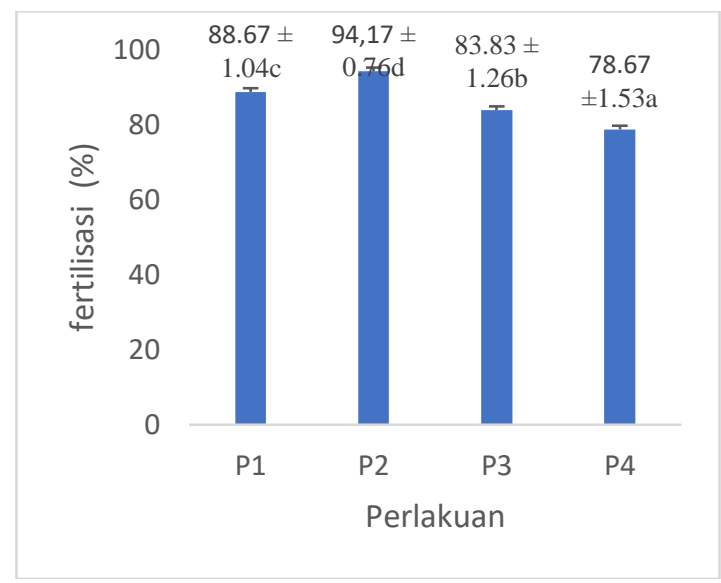

Gambar 3. Fertilisasi

\section{Daya Tetas (HR)}

Berdasarkan penelitian yang sudah di lakukan daya tetas telur tertinggi terdapat pada $\mathrm{P} 2$ sebesar $94,17 \%$, selanjutnya pada $\mathrm{P} 1$ sebesar $88,67 \%$, kemudian pada P3 sebesar $83,83 \%$, dan nilai terendah pada $\mathrm{P} 4$ yaitu $78,67 \%$.

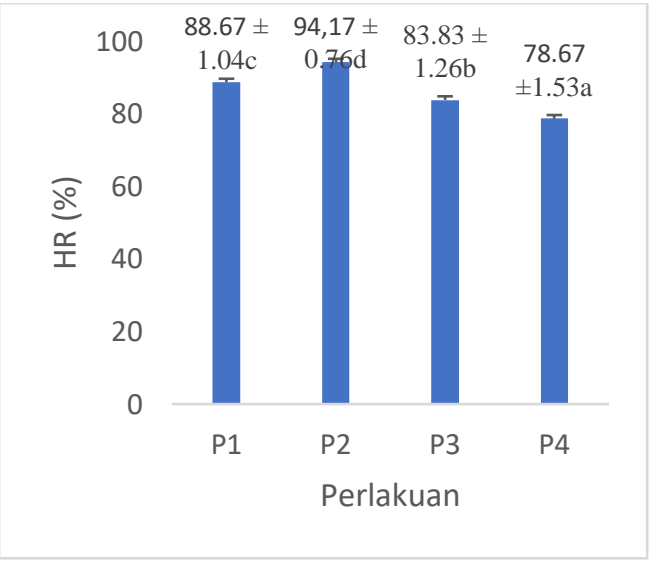

Gambar 4. Daya Tetas

\section{Kelangsungan Hidup (SR)}

Berdasarkan hasil yang di dapatkan pada penelitian, kelangsungan hidup ikan badut tertinggi dapat di lihat pada P2 sebesar $82,84 \%$, selanjutnya pada P1 sebesar $82,15 \%$, kemudian pada P3 sebesar $80,94 \%$, dan yang terendah ada pada P4 sebanyak $80,11 \%$. Hasil uji statistik menunjukkan bahwa semua perlakuan tidak berbeda nyata dengan perlakuan lainnya yaitu P1, P2, P3 P4.

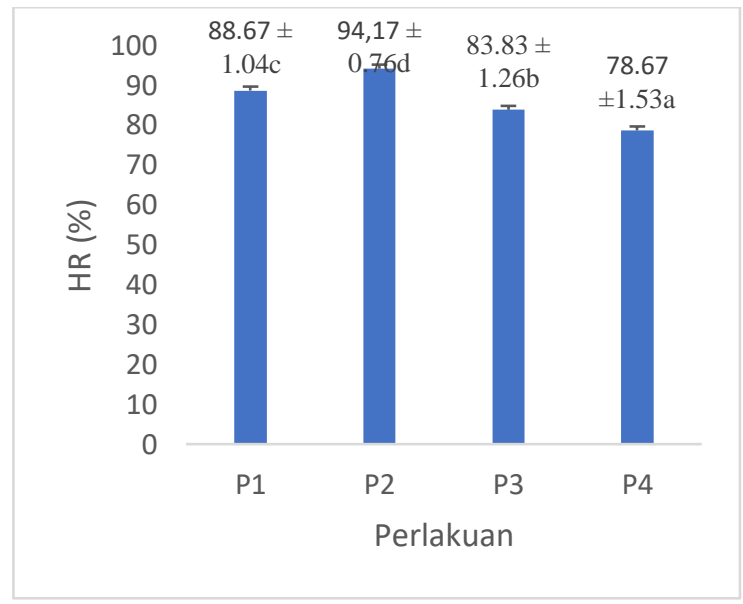

Gambar 5. Kelangsungan Hidup

\section{Kualitas Air}

\begin{tabular}{|c|c|c|c|c|c|c|}
\hline \multirow[t]{2}{*}{ No. } & \multirow[t]{2}{*}{ Parameter } & \multicolumn{4}{|c|}{ Perlakuan } & \multirow[t]{2}{*}{ Acuan } \\
\hline & & $\mathrm{P} 1$ & $\mathrm{P} 2$ & P3 & $\mathrm{P} 4$ & \\
\hline 1 & Suhu $\left({ }^{\circ} \mathrm{C}\right)$ & $27,6^{\circ} \mathrm{C}$ & $27,9^{\circ} \mathrm{C}$ & $27,4^{\circ} \mathrm{C}$ & $27,6^{\circ} \mathrm{C}$ & $\begin{array}{l}27-32^{\circ} \mathrm{C} \\
\text { (Setiawati } \\
\text { et al., } \\
\text { 2010). }\end{array}$ \\
\hline
\end{tabular}


Jurnal Perikanan (2021) Volume 11. No. 2 : 209-217

DOI : https://doi.org/10.29303/jp.v11i2.257

\begin{tabular}{|c|c|c|c|c|c|c|}
\hline 2 & $\mathrm{DO}(\mathrm{mg} / \mathrm{l})$ & $5,2 \mathrm{mg} / \mathrm{l}$ & $5,4 \mathrm{mg} / \mathrm{l}$ & $5,8 \mathrm{mg} / \mathrm{l}$ & $5,7 \mathrm{mg} / 1$ & $\begin{array}{l}5-6 \mathrm{mg} / \mathrm{l} \\
\text { (Setiawati } \\
\text { et al., } \\
2010 \text { ). }\end{array}$ \\
\hline 3 & $\mathrm{pH}$ & 7,8 & 7,6 & 7,8 & 7,8 & $\begin{array}{l}6,7-8,6 \\
\text { (Setiawati } \\
\text { et al., } \\
\text { 2010). }\end{array}$ \\
\hline
\end{tabular}

PEMBAHASAN

Fertilisasi

Fertilisasi adalah interaksi kombinasi yang memanfaatkan sel telur dengan sel spermatozoa untuk membentuk zigot. Berdasarkan penelitian yang telah dilakukan, pembuahan telur yang paling tinggi peningkatannya adalah pada P2 sebesar 94,17\%, dan nilai terendah pada P4 yaitu 78,67\%. Hasil uji statistik menyatakan bahwa $\mathrm{P} 2$ pada dasarnya sama dengan P1, P3, P4. Nilai tingkat perlakuan yang didapat adalah normal sebesar $86,33 \%$. Seperti yang ditunjukkan oleh Setiawati et al. (2012), tingkat pembuahan adalah tingkat telur yang terbuahi oleh jumlah telur yang di keluarkan dalam proses pemijahan. Nilai tingkat pemijahannya sangat tinggi. Fertilisasi yang umumnya terjadi di luar tubuh induknya. Keberhasilan proses fertilisasi di tentukan oleh kemampuan sperma untuk membuahi sel telur. Hubungan telur dengan substrat pada umumnya akan dipengaruhi oleh daya tahan telur karena adanya faktor pembatas. faktor pembatas termasuk jumlah telur yang disebarkan yang tidak terbuahi, beberapa telur yang rusak disebabkan oleh jamur dan bakteri.

Penentuan taraf keberhasilan fertilisasi telur dapat ditemukan pada perubahan warna di mana telur yang terbuahi berwarna transparan sedangkan telur yang tidak dibuahi berwarna putih pucat. Dari penelitian yang dilakukan diketahui bahwa tingkat persentase yang paling tinggi pada perlakuan dan ulangan menggunakan menggunakan substrat genteng adalah perlakuan dengan tingkat persentase yang paling tinggi yaitu $94,17 \%$, kemudian pada saat itu pemanfaatan substrat keramik sebesar $88,67 \%$, pemanfaatan substrat menggunakan paralon sebesar 83,83\%, dan perlakuan dengan pemanfaatan gerabah dengan kecepatan persentase $78,67 \%$. Dari keempat substrat yang digunakan. Secara umum, setiap substrat keras yang dicoba dapat digunakan untuk menempeli telur ikan badut. Hal ini menunjukkan bahwa berbagai substrat keras dapat dimanfaatkan sebagai tempat untuk menempelkan telur ikan badut. Menurut Richmond (1997), menunjukkan bahwa planula tidak melekat dalam sedimen yang longgar dan tidak cocok, jika terjadi penempelan maka daya kelangsungan hidup akan rendah.

\section{Daya tetas (Hatching rate)}

Berdasarkan hasil pengamatan yang di lakukan, daya tetas telur ikan badut sangat tinggi, nilai tingkat penetasan adalah 95\%. Menurut Sutarjo (2014), tingkat penetasan adalah tingkat jumlah telur yang menetas tergantung pada jumlah telur yang terpertilisasi. Tercapainya daya tetas telur yang tinggi dapat dipengaruhi oleh beberapa komponen antara lain kualitas telur, kualitas air, dan penanganan 
saat menetas. Salah satu faktor tingkat tinggi dan rendahnya penetasan adalah jenis substrat yang digunakan untuk tempat melekat dalam proses penetasan. Jenis substrat yang tidak sesuai dapat mempengaruhi tingkat penetasan. Perlakuan penelitian dengan menggunakan substrat genteng merupakan perlakuan dengan laju penetasan paling tinggi sebesar $94,17 \%$, dilanjutkan dengan perlakuan menggunakan substrat keramik dengan penetasan sebanyak $88,67 \%$, perlakuan menggunakan substrat paralon sebesar $83,83 \%$, dan perlakuan menggunakan substrat gerabah dengan penetasan $78,67 \%$. Hal ini sesuai dengan penelitian Hartami (2012), menyatakan bahwa keberhasilan sistem produksi sangat berhubungan dengan keberadaan substrat. Substrat yang tidak sesuai akan menyebabkan proses penetasan telur mengalami kegagalan atau tertunda. Sedangkan substrat yang layak akan membentuk benih yang berkualitas dan dalam jumlah yang banyak. Berdasarkan anilisis sidik ragam ANNOVA menerangkan bahwa adanya pengaruh jenis substrat yang tidak sesuai pada taraf penetasan telur ikan badut $(\mathrm{P}<0,05)$. Hal ini menunjukkan bahwa berbagai jenis substrat dalam penelitian ini berpengaruh nyata terhadap taraf penetasan telur ikan badut. Perlakuan substrat genteng pada dasarnya berbeda nyata dengan substrat keramik, perlakuan menggunakan substrat genteng berbeda nyata dengan perlakuan menggunakan substrat paralon, perlakuan menggunakan substart genteng berbeda nyata dengan perlakuan menggunakan substrat gerabah. Hal ini menunjukkan bahwa masing-masing jenis perlakuan substrat berpengaruh nyata terhadap laju penetasan telur ikan badut.

\section{Kelangsungan Hidup}

Berdasarkan hasil penelitian yang telah di lakukan terhadap kelangsungan hidup ikan badut menggunakan substrat genteng, keramik, paralon, dan gerabah. Diketahui bahwa kelangsungan hidup dalam masing- masing substrat tidak sama pada setiap perlakuan. Perlakuan pada substrat genteng memiliki persentase kelangsungan hidup paling tinggi yaitu sebesar $82,84 \%$, kemudian pada perlakuan yang menggunakan substrat keramik sebesar $82,15 \%$, pada perlakuan yang menggunakan substrat paralon sebesar $80,94 \%$, dan pada perlakuan yang menggunakan substrat gerabah adalah $80,11 \%$. Telur yang ditetaskan pada substrat genteng menunjukkan tingkat penetasan yang paling tinggi yaitu sebesar $82,84 \%$.

Menurut tingkat penetasan, jenis substrat genteng ini berguna untuk sistem produksi karena genteng dapat mempengaruhi daya tahan hidup larva. Tingkat kelangsungan hidup merupakan perbandingan jumlah ikan yang di tebar. Faktor yang berpengaruh nyata terhadap daya tahan larva adalah faktor makanan dan faaktor lingkungan. Seperti yang ditunjukkan oleh Raharjo et al. (2016) tahap larva merupakan periode yang sangat mendasar, karena tahap larva sangat sensitif terhadap faktor lingkungan dan ketersediaan makanan. Tingginya kelangsungan hidup ikan disebabkan oleh pengaruh padat tebar, semakin tinggi padat penebaran ikan, semakin tinggi perlawanan makhluk hidup di dalamnya, misalnya kondisi oksigen, makanan, 
mudahnya parasit yang menyerang ikan, dan mempercepat penurunan kualitas air. Daya tahan larva juga umumnya ditentukan oleh ketersediaan pakan sebagai sumber energi untuk pertumbuhan. Passing juga disebabkan oleh ukuran dan umur ikan yang masih belum mampu bertahan dengan baik. Kelangsungan hidup juga sangat berkaitan dengan kualitas air, dimana jika kualitas air bagus maka nilai SR akan bagus dan sebaliknya dengan asumsi kualitas air buruk maka nilai SR bisa berkurang. Hal ini sesuai dengan penilaian Gusman (2014) yang menyatakan bahwa daya tahan tubuh ikan dipengaruhi oleh faktor alam seperti pemeliharaan. Perawatan yang tidak tepat dapat menyebabkan stres pada ikan, sehingga masalah kesehatan ikan berkurang dan dapat menyebabkan kematian.

\section{Kualitas Air}

Kualitas air merupakan faktor fisik dan zat yang dapat mempengaruhi lingkungan media pendukung yang dapat diperkirakan secara langsung. Selama pemeliharaan ikan badut, kualitas air diperkirakan mencakup oksigen terlarut dari 5,2-6,5, suhu sekitar $27-30^{\circ} \mathrm{C}$, $\mathrm{pH}$ dari 7-8. Hasil pengukuran diatas dapat diketahui bahwa selurh parameter dalam keadaan normal untuk pertumbuhan ikan badut. Setiawati dan Hutapea (2010), menyatakan bahwa kondisi air yang sesuai untuk aktivitas budidaya ikan badut adalah memiliki nilai parameter derajat keasaman yang ideal pada kisaran 6,7-8,6, oksigen yang terlarut lebih dari $5 \mathrm{mg} / \mathrm{l}$, dan suhu yang berkisar dari $27-32^{\circ} \mathrm{C}$. Faisyal (2016), menyatakan bahwa kualitas air mempengaruhi budidaya karena kelayakan suatu perairan sebagai lingkungan hidup dikendalikan oleh sifat fisik dan senyawa air seperti suhu, derajat keasaman, oksigen terlarut, kandungan amoniak dan beberapa parameter yang berbeda.

\section{KESIMPULAN}

Berdasarkan hasil penelitian ini dapat di simpulkan bahwa penambahan substrat berupa genteng, keramik, paralon dan gerabah berpengaruh nyata terhadap fertilisasi dan daya tetas telur pada pemijahan ikan badut. Sedangkan tingkat kelangsungan hidup tidak berpengaruh nyata. Kelangsungan hidup ikan badut tertinggi pada penelitian ini di peroleh sebesar $82,84 \%$.

\section{DAFTAR PUSTAKA}

Ade, H.M., Nuraini. \& Netty, A. (2021). Pengaruh substrat berbeda terhadap pemijahan dan penetasan telur ikan zebra pink danio. Jurnal Akuakultur Sebatin,. 2(1).

Ahmad, F., M. Nasir. (2017). Pengaruh penambahan probiotik dengan dosis berbeda pada pakan terhadap pertumbuhan dan rasio konversi pakan (Fcr) ikan nila. Jurnal Median, 9(1).

Akmal, A., Mauli, K., Karma., Ilyas. (2020). Aplikasi teknologi program pengembangan produk unggulan daerah (PPPUD); Produksi ikan hias karang lestari di pulau Barrang Lompo, Makasar, Sulawesi selatan. Jurnal Pengabdian Kepada Masyarakat. 4(4).

Anyodin, O.Y., Yulianus, L., Nicodemus, D. (2020). PEngaruh perbedaan substrat terhadap pertumbuhan ikan sidat (Anguila bicolor bicolor) di dalam wadah budidaya. Jurnal Aquatik, 3(1). 
Arifin, Y. (2016). Pertumbuhan Dan Survival Rate Ikan Nila ( Oreochromis. Sp ) Strain Merah Dan Strain Hitam Yang Dipelihara Pada Media Bersalinitas. Jurnal Ilmiah, 16(1), 159-166

Aprelia, M.T., Deidy, A. \& Walter, B. (2018). Pertumbuhan dan pematang gonad ikan giru (Amphiprion clarkia) yang diberi pakan mengandung hormone oodev. Jurnal Teknologi perikanan dan kelautan, 9(2).

Edi Rudi., Dedi. S., Harpasis, S.S., John, I.P. (2005). Affinitas penempelan telur larva karang (Scleractinia) pada substrat keras. Jurnal Ilmiah ilmu perikanan dan ilmu kelautan, 12(2).

Edwar, A., Hengky, J.S. \& Revol, D.M. (2016). Pengaruh penggunaan substrat yang berbeda terhadap daya tetas telur dan sintasan hidup larva ikan lele sangkuriang (Clarias sp). Jurnal Budidaya perairan, 4(1), 715.

Handrina, S. \& Akhmad, T.M. (2020). Persentase penetasan dan performa pertumbuhan benih ikan Clown (Amphiprion percula). Jurnal Biosains Pascasarjana, 22.

H A Sahusilawane., M Z Junior., M A Suprayudi., D T Soelistyowati., L I T A Tumbeleka. \& I Effendi. (2019). Paired clownfish (Amphiprion sp.) spawning pattern in indoor rearing system.

Jonathan Aldo., Juni Susanti. B., Yenny, M.F.H. (2021). Pengaruh pemberian pakan berbeda terhadap pertumbuhan ikan badut (Amphirion percula) pada media resirkulasi. Jurnal Penelitian terapan perikanan dan kelautan.

Khairani, L. \& Junita, P. (2020). Pengaruh substrat yang berbeda terhadap pemijahan ikan mas koki oranda (Carrasius auratus Linnaeus). Jurnal Pionir LPPM Universitas Asahan, 5(2).

Lilis Farianti. (2015). Pola hubungan antara jenis anemone dengan ikan badut (Amphiprion oscellaris) di perairan daerah pulau pucung kabupaten bintan provinsi kepulauan riau.

Merlia, D.J., Supono. \& Suparmono. (2019). Kajian sintasan dan pertumbuhan benih ikan badut Amphiprion percula (Bloch, 1801) yang di pelihara pada media salinitas yang berbeda. Jurnal Kelautan, 12(2).

Muhammad Mulqan., Sayyid, A. E. R., Irma, D. (2017). Pertumbuhan dan kelangsungan hidup benih ikan nila gesit (Oreochromis niloticus) pada sistem akuaponik dengan jenis tanaman yang berbeda. Jurnal Ilmiah Mahasiswa Kelautan Dan Perikanan Unsiyah, 2(1).

Muhammad, Z.L., Sri, P. \& Muhammad, M. (2015). Pengaruh anemone (Heteractis magnicifa) terhadap vitalitas ikan badut (Amphiprion oscellaris) untuk meminimalisasi penggunaan karang hidup pada akuarium laut buatan.

Nia, J.S., Usma, M.T., Niken, A.P. (2018). Pengaruh substrat filter yang berbeda pada sistem resirkulasi terhadap laju pertumbuhan ikan selais (Ompok hypopthalmus).

Nuri, L., Afrizal, H., Mahendra. (2016). Fertilisasi dan daya tetas telur ikan tawes (Puntius javanicus) dari sperma pasca penyimpanan pada temperature $4^{\circ} \mathrm{C}$. Jurnal perikanan tropis, 3(1).

Paraditya, N.A., Mas Eriza. \& Azrita. (2015). Aspek reproduksi ikan badut 
Jurnal Perikanan (2021) Volume 11. No. 2 : 209-217

DOI : https://doi.org/10.29303/jp.v11i2.257

(Amphiprion

Pomancentridae) di perairan

Mentawai.

Rachmawati, D., Samidjan, I. (2016).

Analisis Tingkat Kecerahan Warna

Ikan Platy Pedang (Xiphophorus

helleri) Melalui Penambahan

Astaxanthin Dengan Dosis Berbeda

Pada Pakan Komersial. PENA Akuatika, 13(1), 58-67.

Ramses, N., Revol, D.M., Winda, M. (2015). Penambahan madu dalam pengenceran sperma untuk motilitas spermatozoa, fertilisasi, dan daya tetas telur ikan nila (Oreochromis niloticus). Jurnal Budidaya perairan, 3(1).

Sri, W., Khaerul, M., Bagus Dwi, H.S. 2012. Pengaruh jenis substrat penempelan telur terhadap tingkat keberhasilan pemijahan ikan komet (Carassius auratus). Jurnal Perikanan Unram, 1(1).

Syaiful, R.H., Trisna, S. (2016). Pengaruh substrat yang berbeda terhadap tingkat penetasan telur (Hatching Rate) ikan patin (Pangasius pangasius). Jurnal Perikanan dan lingkungan hidup, 5(1).

Syifa, M.D.G., Pande, G.S.J. \& Dewa ayu, A.P. (2020). Pengaruh perbedaan warna wadah kultur terhadap kandungan karotenoid ikan badut (Amphiprion oscellaris). Jurnal of
Current trends in aquatic science, 3(1), 8-14.

Sylvia, S., \& Minggawati, I. (2010). Kualitas Air yang Mempengaruhi Pertumbuhan Ikan Nila (Oreochromis sp.) di Kolam Beton dan Terpal. Journal of Tropical Fisheries, 5, 526-530.

Uswatun, H. (2017). Daya tetas telur dan sintasan larva dari hasil penambahan madu pada bahan pengencer sperma ikan lele sangkuriang (Clarias sp). Jurnal Warta, 54.

Uswatun, H., Ayu Adhita, D. \& Fariq, A. (2020). Pengaruh laju pemuasan secara periodic terhadap pertunbuhan kelangsungan hidup dan kecerahan warna ikan badut (Amphiprion oscellaris). Jurnal Biologi tropis, 20(1), 46-53.

Yufika, S., Helmi, H. \& Syaeful, A. (2019). Penggunaan substrat yang berbeda terhadap fekunditas, derajat penetasan dan kelangsungan hidup pada pemijahan ikan mas koki (Carassius auratus). Jurnal ilmu kelautan dan budidaya perairan, 14(2).

Zulfikar., Erlinza, M. \& Erlangga. (2018). Pengaruh warna wadah terhadap pertumbuhan dan kelangsungan hidup ikan badut (Amphiprion oscellaris). Jurnal Aquatic Sciences, 5(2), 88-92 